\title{
Spatio-Temporal Analysis of Sinuosity of Ghaghara River: A Remote Sensing and GIS Approach
}

\author{
Pawan Kumar Gautam
}

Department of Geology, University of Lucknow, Lucknow, Uttar Pradesh, India

\begin{abstract}
The research work examined the temporal variation in the sinuosity index of the Ghaghara River Middle Ganga plain, India. The calculation of the sinuosity indexes was used mutilated satellite Imageries and Survey of India Toposheets (1:50,000) which is carried out using Arc GIS 10 software. The sinuosity of the channel has been measured is 1.3, 1.2, 1.3, 1.2, 1.2, and 1.3 for year 1975, 1980, 1990, 2000, 2010 and 2018, respectively. The Temporal variation in sinuosity of Ghaghara River has been identified. Sinuosity index variation is induced by the slope of fluvial systems, water discharge. High sinuosity of the river identifies the characteristics of the gentle slope of the river basin which indicate the area becomes more sensitive to the flood. The Spatio-temporal shifting analysis of the river is very susceptible to identify the future trend of the river.
\end{abstract}

Keywords: Ghaghara River, Spatio-Temporal Sinuosity Index, Remote Sensing and GIS

\section{Introduction}

The geometry of the channel platforms studied given by [1]. The channel sinuosity is controlled by channel gradient, sediment load, resistance to lateral erosion of a river and stage of valley development and the structural characteristics of the area through which it flows [2]. The research of the drainage sinuosity index allows evaluating the impact of terrain on the course of the river and vice versa [3]. The tectonically cause gradient steepening lead to heightened channel activity, resulting in accelerated erosion either by incision or by lateral erosion and an increase in sinuosity [4]. The sinuosity changes have been correlated with discharge and sediment load changes at the inter-flow of tributaries [5]. [6] Evaluated a quantitative relationship between regional climatology and sinuosity, and it has been postulated that the rivers, which have more relative variation in discharge, tend to have greater lateral mobility.

\section{Study Area}

The study area is located in the Middle Ganga Plain and geographically it lies between $23^{\circ} 31^{\prime} 51^{\prime \prime}$ and $28^{\circ} 25^{\prime} 20^{\prime \prime} \mathrm{N}$

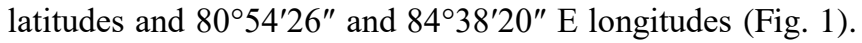
It is the largest tributary of the Ganga by volume and second largest by length. It is a very dynamic river regarding their valley widening and lateral shifting. It exhibits three regional geomorphic surfaces such as Upland Terrace Surface (T2), River valley Terrace surface (T1) and Active Floodplain Surface (T0). These surfaces are made up of loose and unconsolidated materials of sand, silt and clay out of which clay percentage is dominated. Slope towards NW - SE direction.

\section{Methodology}

The study of Ghaghara River carried out using SOI topographic maps of 1:50000 scales for the year 1975 and multi-date satellite imageries including, LANDSAT

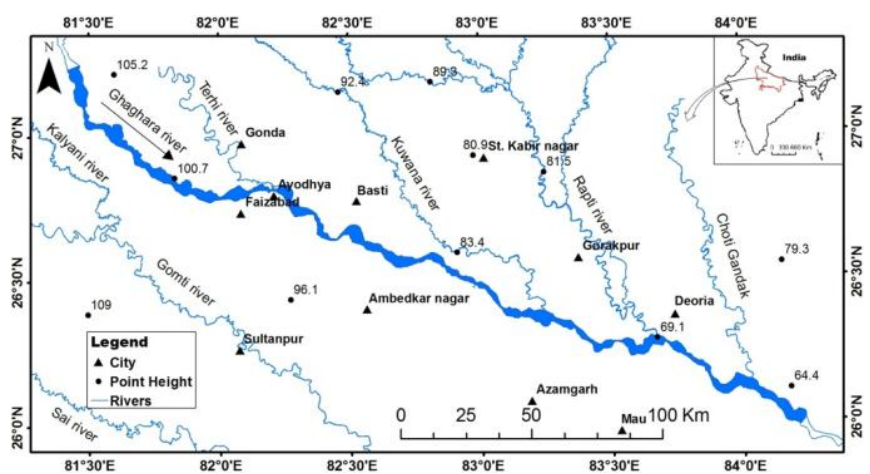

Figure 1: Location map of Study area

Thematic Mapper (TM) for the year 1990, LANDSAT -7 Enhanced Thematic Mapper Plus (ETM+) for the year 2000, LISS-3 for the year (2010) and Landsat-8 Operation land imager (OLI) for the year 2018 have been used with the help of Arc GIS 10 software (Table 1). The Ghaghara River is demarcated into 10 sections (fig. 2 and 3). The Sinuosity index has been determined for all these sections for monitoring the channel pattern. For obtaining the sinuosity index, (SOI) Toposheets at a scale of 1:50000 and Google images were used. By utilization GIS software, i.e. Arc Map and The relevance of Remote sensing images and SRTM data was taken for generating data for river characteristic.

Table 1: specification of the satellite data sets used

\begin{tabular}{|c|c|c|c|c|c|}
\hline $\begin{array}{c}\text { S. } \\
\text { No. }\end{array}$ & $\begin{array}{c}\text { Satellitel } \\
\text { Toposheet }\end{array}$ & $\begin{array}{c}\text { Data } \\
\text { source/Sensor }\end{array}$ & Band & Resolution & Date \\
\hline 1 & Toposheet & Survey of India & - & 50,000 scale & 1975 \\
\hline 2 & Landsat-TM & TM & 7 & $30 \mathrm{~m}$ & 1990 \\
\hline 3 & Landsat-7 & ETM+ & 8 & $30 \mathrm{~m}$ & 2000 \\
\hline 4 & Resourcesat-I & LISS-3 & 4 & $23.5 \mathrm{~m}$ & 2010 \\
\hline 5 & Landsat-8 & OLI & 11 & $30 \mathrm{~m}$ & 2018 \\
\hline
\end{tabular}

\section{Result and discussion}

Volume 8 Issue 9, September 2019 www.ijsr.net 


\section{International Journal of Science and Research (IJSR) \\ ISSN: 2319-7064}

Research Gate Impact Factor (2018): 0.28 | SJIF (2018): 7.426

\subsection{Spatio-temporal analysis of Sinuosity}

The sinuosity index has been determined for all these sections for monitoring the channel Sinuosity parameters of the Ghaghara River. Rivers with a sinuosity index 1.3 shows the sinuous in nature and 1.5 are lead to meandering nature were measured using the procedure [7] (Table 2).

$$
\mathrm{Sl}=\mathrm{Cl} / \mathrm{Vl}
$$

The Ghaghara River is estimated to be $403.6 \mathrm{~km}$ long, and the section was divided into equal length reaches each having a length of $40 \mathrm{~km}$ long demarcated in 10 (Fig. 2). Ghaghara River possesses sinuosity index 1.1 to 1.3 having the sinuous pattern. The sinuosity was measured using the following equation for each reach. This Indicates temporal increasing sinuosity. In 1975 the Ghaghara was a straight single channel-river with a sinuosity $(<1.5)$, but till of year 2018 the sinuosity values were examined (>1.5) and the river exhibited a braided multi-channel river, in the year 1990 the sinuosity parameters decreased sharply while again it increased during 2000 and 2018.

Table 2: Classification of the sinuosity index and channel pattern based on [7]

\begin{tabular}{|c|c|c|}
\hline Number of channels & Ratio & Channel Pattern \\
\hline Single channel & $<1$ & Straight \\
\hline Wandering channel & $1-1.3$ & Low sinuous \\
\hline Braided channel & $1.3-1.5$ & High sinuous \\
\hline Anastomosing channel & $>1.5$ & Meandering \\
\hline
\end{tabular}

For the year 1980, 1990, 2000, 2010, 2018 the total average channel length is $392,404,389,395,404 \mathrm{~km}$, valley length are $319.8,317.4,320.1,321.1,319.8$ and calculated sinuosity index $1.2,1.3,1.2,1.2,1.3$ respectively. The sinuosity index (SI) of the Ghaghara shows the sinuous in nature (Table 3). The Spatio-temporal variation in sinuosity of Ghaghara River well defined. (Fig. 3) For the year 1975 the total average channel length is $403, \mathrm{~km}$. Valley length is $320.9 \mathrm{~km}$, calculated sinuosity index 1.3 for the year 1975 respectively (Table 3 and 4) and stretches of Ghaghara River showing in (Fig. 2).

Table 3: Sinuosity analyses of Ghaghara River for year 1975

\begin{tabular}{|c|c|c|c|}
\hline $\begin{array}{c}\text { River } \\
\text { Stretches }\end{array}$ & $\begin{array}{c}\text { Channel Length } \\
(\text { Km })\end{array}$ & $\begin{array}{c}\text { Valley Length } \\
(\text { Km })\end{array}$ & $\begin{array}{c}\text { Sinuosity } \\
\text { Index }\end{array}$ \\
\hline G- 1 & 40.3 & 28.4 & 1.4 \\
G- 2 & 40.3 & 35.0 & 1.2 \\
G- 3 & 40.3 & 34.9 & 1.2 \\
G- 4 & 40.3 & 30.8 & 1.3 \\
G- 5 & 40.3 & 32.6 & 1.2 \\
G- 6 & 40.3 & 31.4 & 1.3 \\
G- 7 & 40.3 & 32.7 & 1.2 \\
G- 8 & 40.3 & 32.0 & 1.3 \\
G- 9 & 40.3 & 33.0 & 1.2 \\
G- 10 & 40.3 & 30.1 & 1.3 \\
Total & 403 & 320.9 & 1.3 \\
\hline
\end{tabular}

The calculated sinuosity indexes show the understanding of the association between the attributes of the river basin and the procedures in the watershed and the river channel. According to [8] "it has been possible to identify the characteristics of channel pattern change as a response to flood flows." The sinuosity also varies because of the regions of the gentle slope or low fall regions become more sensitive to flooding. This seems to receive heavy precipitation during monsoon cause flood. The Ganga plain occurrence faces the flood disaster problem annually. The flood has extremely been destroying crops, Villages and property.

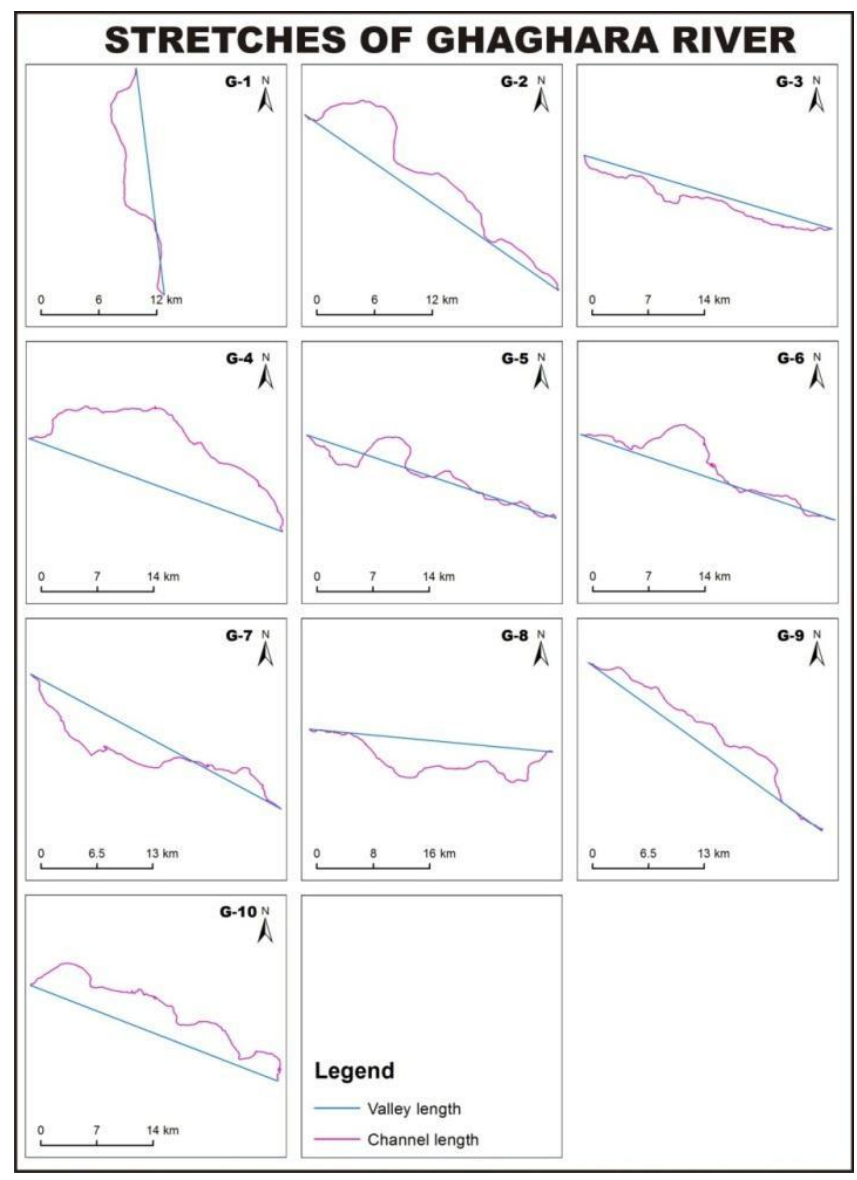

Figure 2: Stretches of Ghaghara River

Table 4: Spatio-temporal sinuosity index of Ghaghara River

\begin{tabular}{|c|c|c|c|}
\hline Year & $\begin{array}{c}\text { Channel Length } \\
(\mathrm{Km})\end{array}$ & $\begin{array}{c}\text { Valley Length } \\
(\mathrm{Km})\end{array}$ & $\begin{array}{c}\text { Sinuosity } \\
\text { Index }\end{array}$ \\
\hline 1975 & 403 & 320.9 & 1.3 \\
1980 & 392 & 319.8 & 1.2 \\
1990 & 404 & 317.4 & 1.3 \\
2000 & 389 & 320.1 & 1.2 \\
2010 & 395 & 321.1 & 1.2 \\
2018 & 404 & 319.8 & 1.3 \\
\hline
\end{tabular}

4.2. Flood effect in Ghaghara River Flood effect on Ghaghara River 


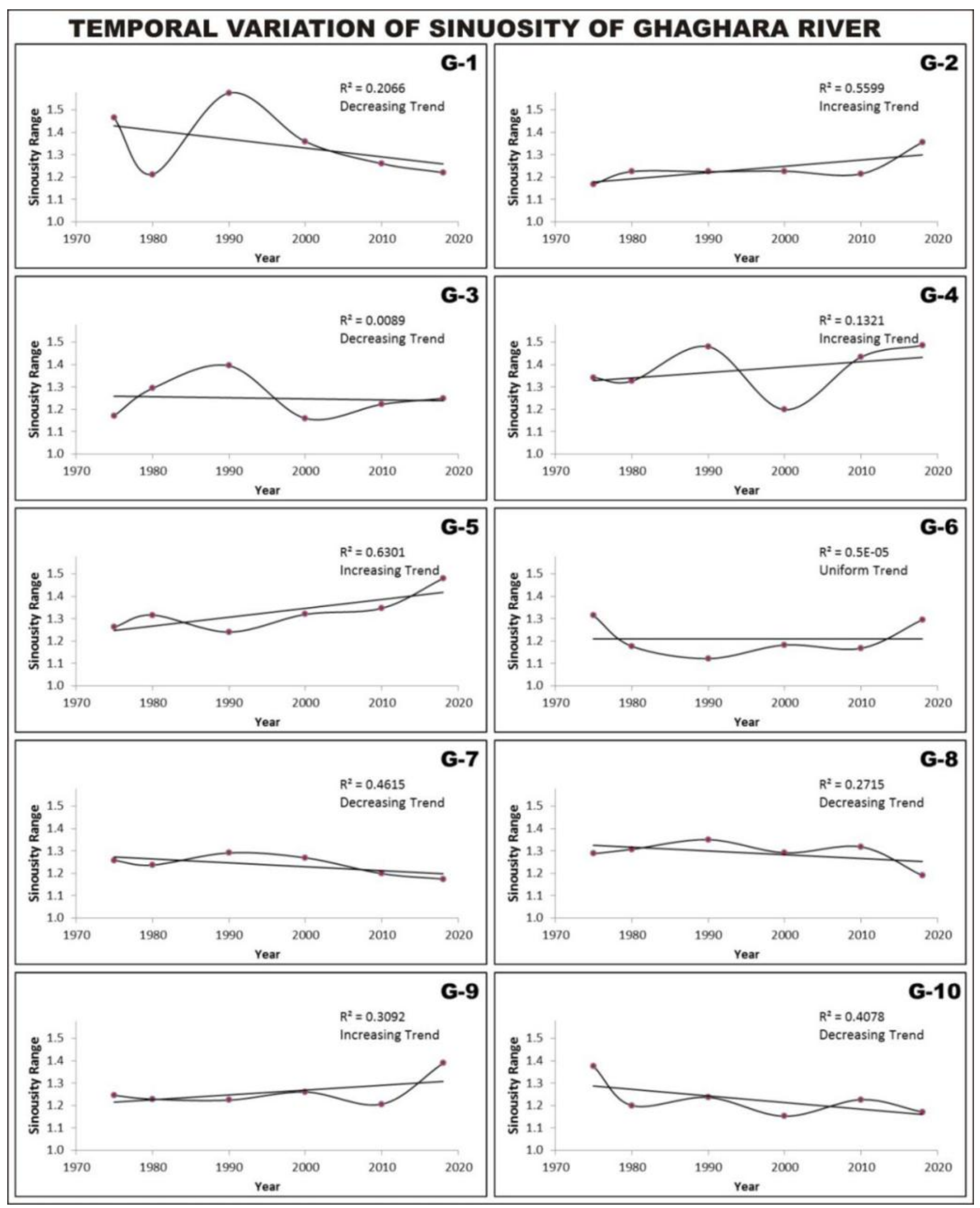

Figure 3: Temporal variation of Sinuosity of Ghaghara River

\section{Conclusions}

The Spatio-temporal shifting analysis is very susceptible to identify the future behavior of the river. In 1975 the Ghaghara measured sinuosity $(<1.5)$, but till of year 2018 the sinuosity values were examined $(>1.5)$ and in the year
1990 the sinuosity parameters decreased sharply while again it increased during 2000 and 2018. The Ghaghara Sinuosity index is indicating high sinuous in nature due to high discharges and sudden reduction in gradients as well as flow velocity in the channel during the river's different flow conditions. The high discharge during

\title{
Volume 8 Issue 9, September 2019
}

\author{
www.ijsr.net
}


the monsoon is the most prominent effective factor behind the flood of the Ghaghara River during its course. This seems to be a heavy rainfall receiving area in the Ghaghara River Basin. The result reveals that morphological activity which indicates mature stage of topographic evolution and erosion on the hydrological significance as well and analysis provides information that identification of flood process to study of Sinuosity indexes leading destroyed infrastructural equipment and houses and agricultural plants. The Spatiotemporal shifting analysis of the river is very useful to identify the behavior of the river.

\section{References}

[1] Schumm. S.A., "Sinuosity of alluvial rivers on the Great Plains." Geol Soc Am Bull 74: 1089-1100, 1963.

[2] Prasad, N., "Some aspects of meandering streams of the Barakar basin and their sinuosity indexes, IV, (Sharma $\mathrm{H}$ $\mathrm{S}$, Eds.) Perspectives in geomorphology-essays on Indian geomorphology, pp. 93-101., 1982.

[3] Panda, P.C., Bora, H.N., "A study on sinuosity index of Siang River and its major tributaries: Arunachal Pradesh.” In: vol. I, (R.K. Rai, A.C. Mahapatra and N.D. Goel, Eds. Environmental management: physioecological facets, Rawat publications, New Delhi, pp. 97-102, 1992.

[4] Keller, E., Pinter, N., "Active tectonics: earthquake, uplift and landscape," ( $1^{\text {st }}$ ed.) New Jersey: Prentice Hall, pp. 338., 1996.

[5] Timar, G., "Controls on channel sinuosity changes: a case study of the Tisza River, the Great Hungarian Plain." Quaternary Science Review., vol.22(20), pp. 2199-2207, 2003.

[6] Barbour, J.R., Strark, C.P., Lin, C.W., Chen, H., Horng, M.J., Ko, C.P., Yi, T.C., Tsai, T.T., Chang, W. S., Lee, S.P., Huang, C., "Magnitude frequency distributions of boundary shear along a rapidly eroding bedrock river." Geophysics Research Letter, 2009.

[7] Leopold L.B., Wolman, M.G., Miller, J.P., "Fluvial processes in geomorphology. San Francisco," WH Freeman and Co, pp. 520, 1964.

[8] Hitchcock, D., "Channel pattern changes in divided reaches: an example in the coarse bed material of the Forest of Bowland. In: (KJ Gregory, Ed.) River Channel Changes, Wiley, Chichester, pp. 206-220., 1977.

\section{Author Profile}

Pawan Kumar Gautam received the M.Sc Degree from University of Lucknow, Lucknow, Uttar Pradesh, India. Currently, he is pursuing in Ph.D Degree at University of Lucknow, Lucknow, Uttar Pradesh, India 